\title{
Polypharmacy, inappropriate medication use and associated factors among brazilian older adults
}

\section{Polifarmácia, uso de medicamento inapropriado e fatores associados em idosos brasileiros}

Juliana Lima Constantino', Ronielly Pereira Bozzi', Gustavo Pinheiro Machado Motta de Souza', Renan Marchesi', Antonio José Lagoeiro Jorge', Dayse Mary da Silva Correia², Maria Luiza Garcia Rosa ${ }^{3}$, Fabíola Giordani ${ }^{1}$ (D), Valéria Troncoso Baltar ${ }^{1}$

'Departamento de Epidemiologia e Bioestatística, Instituto de Saúde Coletiva, Universidade Federal Fluminense (UFF) - Niterói (RJ), Brasil. ²Departamento de Clínica Médica, Universidade Federal Fluminense (UFF) - Niterói (RJ), Brasil.

${ }^{3}$ Departamento de Fundamentos de Enfermagem e Administração, Universidade Federal Fluminense (UFF) - Niterói (RJ), Brasil.

How to cite: Constantino JL, Bozzi RP, Souza GPMM, Marchesi R, Jorge AJL, Correia DMS, et al. Polypharmacy, inappropriate medication use and associated factors among brazilian older adults. Cad Saúde Colet, 2020;28(3):400-408. https://doi.org/10.1590/1414-462X202028030245

\begin{abstract}
Background: Population aging is still an important worldwide phenomenon. Elderly people suffer from multiple chronic diseases that require the use of several drugs, and this demographic scenario fosters the increased prescription of multiple drugs, or Polypharmacy (PP) and Potentially Inappropriate Medication (PIM). Objective: This study aimed to identify the prevalence rates and associated factors of PP and PIM in Brazilian older adults. Method: The prevalence of PIM use and PP was estimated in a sample of 222 patients enrolled in the Family Health Program in Niterói, Brazil. Logistic regression models were used to analyze the data. Age and sex were kept in the models as potential confounding factors. Results: PP and PIM use presented prevalence rates of 23.9 and $24.8 \%$, respectively. PP was associated with body mass index, coronary heart disease, diabetes mellitus, and a number of comorbidities, whereas PIM use was associated with PP. Conclusion: The prevalence rates of PP and PIM use found were lower than those reported in previous studies. This could be a result of differences in availability of drugs or prescribing habits. Multiple chronic diseases were associated with PP. These results suggest that more care should be taken in prescribing for the elderly population.
\end{abstract}

Keywords: drug therapy; epidemiology; older adults.

\section{Resumo}

Introdução: O envelhecimento populacional é um fenômeno mundial. Os idosos apresentam mais comorbidades e usam vários medicamentos, cenário que aumenta a prescrição de polifarmácia (PF) e o uso de medicamentos potencialmente inapropriados (MPIs). Objetivo: O objetivo do estudo foi identificar a prevalência e os fatores associados à PF e aos MPIs em idosos brasileiros. Método: Foi utilizada uma amostra de 222 idosos inscritos no Programa Médico de Família em Niterói, Brasil (Estudo Digitalis). Foi estimada a prevalência de PF e MPIs. Foram usados modelos de regressão logística. Idade e sexo foram mantidos nos modelos como possíveis fatores de confusão. Resultados: A prevalência de PF foi de $23,9 \%$ e de MPIs $24,8 \%$. A PF foi associada com índice de massa corpórea, doença coronariana, diabetes mellitus e número de comorbidades; já MPIs foram associados com PF. Conclusão: A prevalência de PF

Study carried out at Departamento de Epidemiologia e Bioestatística, Instituto de Saúde Coletiva, Universidade Federal Fluminense (UFF) - Niterói (RJ), Brasil.

Correspondence: Juliana Lima Constantino. E-mail: jlconstantino@id.uff.br

Financial support: none.

Conflict of interests: nothing to declare.

Received on: Sep. 03, 2018. Accepted on: Aug. 17, 2019
This is an Open Access article distributed under the terms of the Creative Commons Attribution License, which permits unrestricted use, distribution, and reproduction in any medium, provided the original work is properly cited. 
e MPIs, embora elevada, foi menor do que a evidenciada em outros estudos. Isso pode ser reflexo das diferenças na disponibilidade das medicações e nos hábitos de prescrição. A PF foi associada à presença de múltiplas comorbidades, visto que sempre é necessário o uso de várias drogas para a manutenção terapêutica. Os resultados deste estudo demonstram que ainda é preciso maior cuidado na prescrição de pacientes idosos.

Palavras-chave: tratamento farmacológico; epidemiologia; idoso.

\section{INTRODUCTION}

Population aging is still an important worldwide phenomenon. In addition, the budget for medical care has been rising not only because of demographic changes, but also because of the need to improve acute care for this specific population group'. Studies have shown that the number of older adults (aged $\geq 60$ years) in the world is expected to increase by more than double - from 841 million people in 2013 to over 2 billion in 2050². This fact has increased the prevalence of chronic diseases, representing a major challenge for the health care system. Moreover, health care providers work in a culture that facilitates diagnosing and prescribing, paying relatively little attention to de-prescribing or reducing chronic medications. This can lead to overtreatment, drug-related illnesses ${ }^{3}$ and falls, which are leading causes of injuries, hospitalization, and deaths in older adults ${ }^{4}$.

This demographic scenario has raised the prescription of multiple drugs or Polypharmacy (PP), which is defined in most of recent studies as the concomitant use of five or more medications ${ }^{5-7}$. Elderly people suffer from multiple chronic diseases that require the use of several drugs, so they use more drugs per capita than other population strata. An US study conducted with older adults found that an overwhelming majority $(73 \%)$ of this population with three or more chronic conditions makes use of five or more prescription drugs. Similar drug use was found in Europe, where $62 \%$ of the elderly population takes at least six medications per day ${ }^{8}$.

Polypharmacy, combined with changes in liver and kidney metabolism intrinsic to aging, can culminate in adverse drug reactions (ADRs). Up to $10 \%$ of hospital admissions among older adults are attributable to ADRs, and $50 \%$ of them are avoidable. PP is also often associated with the use of Potentially Inappropriate Medication (PIM), delirium, poor treatment adherence, falls, declines in cognitive and physical functioning, noncompliance with treatment, mortality, and increasing costs to patients and to the health care system ${ }^{10-12}$.

This study aimed to evaluate the prevalence of PP and PIM use and associated factors in the elderly population assisted by the Family Health Program in Niterói, Brazil. Recognition of these factors may clarify the conditions under which those problems occur and assist with guiding more appropriate drug prescription. This, in turn, may lead to reduced morbidity, mortality and health care costs.

\section{METHOD}

\section{Study sample}

Data were collected from a cross-section prevalence study of chronic diseases, the Digitalis study, conducted with patients enrolled in the Family Health Program in the municipality of Niterói, Brazil. The original sample size was composed of 630 individuals aged $\geq 45$ years, and the data were collected between July 2011 and December 2012. This study included all individuals aged $\geq 60$ years who used at least one medication, totaling 222 patients $^{13}$.

During the first visit to the outpatient unit, a structured questionnaire was used to obtain the patients' clinical history, demographic variables, lifestyle, physical examination, and anthropometric data.

\section{Medication use}

All participants were advised to bring their prescriptions to the visit to the outpatient unit. The question asked was "Have you been taking any medication regularly for the 
past three months?". In the case of positive response, the patient was asked to show the prescription or the medication box, and information on dosage and frequency was recorded. All drugs were codified accordingly to their active pharmaceutical ingredient and dose. Each medication was then checked using the Beers-Fick ${ }^{14}$ and PRISCUS ${ }^{15}$ list tables, and if it was included in either of these tables, it was classified as a PIM. Medications were also classified as Antihypertensive (Diuretics, Beta blockers, Angiotensin-converting enzyme inhibitors (ACEl), Angiotensin Il receptor blockers (ARBs), Calcium Channel Blockers (CCBs), Vasodilators), Nitrates, Antiarrhythmics, Digitalis, Statins, Hypolipidemic agents, Antidiabetics, Analgesics, Non-Steroidal Anti-inflammatory (NSAIDs), Corticosteroids, Antidepressants, Proton Pump Inhibitors (PPIs), H2 blockers, Anticonvulsants, Anticoagulants, Antiplatelet agents, and Thyroid hormones, and Others. The number of medications per class and the total of medications were counted (within those classes). A cutoff point of five or more medications was used to define PP.

\section{Statistical analysis}

The prevalence of PIM and PP among the patients aged $\geq 60$ years who used at least one medication was estimated. Sixteen variables (gender, age, body mass index, skin color, per capita family income, private health insurance, marital status, chronic obstructive pulmonary disease (COPD), coronary heart disease, depression, dyslipidemia, hypertension, diabetes, heart stroke, current smoking status, number of morbidities) were selected as risk factor candidates based on the scientific literature on PP and PIM use ${ }^{16,17}$. The age considered was the number of completed years at the moment of the interview. As for marital status, the patient was asked if they had or not a fixed partner. For the variables depression, heart stroke, dyslipidemia and COPD, the patient was asked if these diseases had been diagnosed by any physician. Regarding diabetes, it was considered if the patient had previous diagnosis or treatment of the disease or glycemic levels $\geq 126$ at the moment of the interview. Concerning hypertension, previous diagnostic, use of medication, or high blood pressure at the moment of the interview were considered. With respect to coronary heart disease, angina, myocardial infarction, stent placement, or cardiovascular surgery until the time of interview were considered. As for current smoking status, the patient was asked if they were or have ever been a smoker and if they had smoked at least 100 cigarettes during their lifetime. The number of morbidities for diabetes, hypertension, dyslipidemia, COPD, depression, and obesity were also counted.

All risk factor candidates for PP and PIM (PP was also added as a risk factor candidate for PIM) were included in a simple logistic regression model, and all variables with $p$-value $>0.20$ were selected for the stepwise multivariate logistic regression analysis. In the final model, the significance level was set at $5 \%$ and age and gender were included as potential confounder variables. Final models had their fit analyzed by residual diagnostics plots (data not shown). Statistical analyses were conducted using the SPSS ${ }^{\circledR} 21$ software for Windows ${ }^{\circledR}$ (IBM/SPSS, Inc., Chicago, IL).

The study was approved by the Research Ethics Committee of the College of Medicine of the Fluminense Federal University under protocol no. 0183.0.258.258.10 and all participants signed a Free and Informed Consent Form prior to data collection.

\section{RESULTS}

In the sample composed of 222 patients assisted at the Family Health Program in Niterói, Brazil, the mean age of participants was 69.6 (SD 7.7) years and 152 of them (68.5\%) were female. The number of medications prescribed per person varied from 1 to 9 (mean of 3.2), in a total of 712. The mean body mass index (BMI) was 28.1 (5.3): 28.9 (5.4) for females and 26.4 (4.5) for males $(p=0.001)$. Prevalence rates of hypertension, diabetes, and coronary heart disease were $91.4,36$ and $15.8 \%$, respectively. On average, the number the morbidities per person was 2.2.

Prevalence of PP was $23.9 \%$ (53 patients) and the prevalence of PIM use, according to Beers-Fick criteria, was $24.8 \%$ ( 55 patients). The PIM prevalence of antidepressants, vasodilators, 
Table 1. Frequency of class medication use and Potentially Inappropriate Medication (PIM) prevalence. Niterói - RJ, Brazil, 2011/2012

\begin{tabular}{|c|c|c|}
\hline Drug class & Medication use frequency & Prevalence of use of PIM \% \\
\hline Antihypertensive & 195 & 10.8 \\
\hline Diuretics & 117 & 0.0 \\
\hline Beta-blockers & 51 & 2.0 \\
\hline ACEls & 109 & 0.0 \\
\hline ARBs & 39 & 0.0 \\
\hline CCBs & 44 & 45.5 \\
\hline Nitrates & 10 & 0.0 \\
\hline Antiarrhythmics & 5 & 100.0 \\
\hline Digitalis & 5 & 100.0 \\
\hline Vasodilators & 13 & 76.9 \\
\hline Anti-diabetics & 58 & 0.0 \\
\hline Statins & 63 & 0.0 \\
\hline Hypolipidemic agents & 5 & 0.0 \\
\hline Analgesics & 4 & 0.0 \\
\hline Anti-inflammatory & 13 & 23.1 \\
\hline Corticosteroids & 8 & 0.0 \\
\hline Antidepressants/Anxiolytics & 27 & 55.6 \\
\hline PPIs/H2 blockers & 39 & 0.0 \\
\hline Anticonvulsants & 3 & 0.0 \\
\hline Anticoagulants & 3 & 0.0 \\
\hline Antiplatelet agents & 49 & 2.0 \\
\hline Thyroid hormone & 8 & 0.0 \\
\hline Total & 222 & 24.8 \\
\hline
\end{tabular}

ACEls - Angiotensin-converting enzyme inhibitors; ARBs - Angiotensin II receptor blockers; CCBs - Calcium Channel Blockers; PPIs - Proton Pump Inhibitors

digitalis and antiarrhythmic users were $55.6 \%$ (15/27), 76.9\% (10/13), 100\% (5/5) and 100\% (5/5), respectively (Table 1 ).

Use of PIM was significantly associated with obesity ( $\mathrm{OR}=2.3, p=0.042), \mathrm{PP}(\mathrm{OR}=4.1$, $p<0.001)$, diabetes mellitus ( $\mathrm{OR}=2.8, p=0.001)$, heart stroke $(\mathrm{OR}=3.0, p=0.033)$, and number of morbidities $(\mathrm{OR}=1.6, p=0.001)$. After adjustments, PIM use was significantly associated with $\mathrm{PP}(\mathrm{OR}=4.05, p<0.001)$ (Table 2).

Unadjusted analysis for PP showed significant effects of $\mathrm{BMI}(\mathrm{OR}=5.8$ for Overweight in relation to under or normal weight, and $\mathrm{OR}=7.4$ for obese compared with under or normal weight; $p=0.002)$, obesity $(\mathrm{OR}=3.4, p=0.002)$, coronary heart disease $(\mathrm{OR}=6.2, p<0.001)$, dyslipidemia $(\mathrm{OR}=2.8, p=0,002)$, diabetes mellitus $(\mathrm{OR}=6.0, p<0,001)$, heart stroke $(\mathrm{OR}=7.1$, $p<0,001)$, and number of morbidities ( $\mathrm{OR}=3.1, p<0.001)$. After adjustment for confounding factors using multivariate logistic regression analysis and control for gender and age, PP was significantly associated with $\mathrm{BMI}(\mathrm{OR}=6.5$ and $5.7, p=0.014)$, coronary heart disease $(\mathrm{OR}=8.8$, 
Table 2. Summary of the logistic regression analysis results for Potentially Inappropriate Medication (PIM) use. Niterói - RJ, Brazil, 2011/2012

\begin{tabular}{|c|c|c|c|c|c|c|}
\hline & \multicolumn{3}{|c|}{ Unadjusted Regression } & \multicolumn{3}{|c|}{ Adjusted Regression } \\
\hline & OR & $\mathrm{Cl}(95 \%)$ & $p$-value & OR & $\mathrm{Cl}(95 \%)$ & $p$-value \\
\hline Gender (male/female) & 1.48 & {$[0.74 ; 2.94]$} & 0.265 & 1.34 & {$[0.65 ; 2.73]$} & 0.426 \\
\hline Age (years) & 0.99 & {$[0.95 ; 1.03]$} & 0.740 & 1.00 & {$[0.96 ; 1.04]$} & 0.994 \\
\hline BMI Classification (WHO) & & & 0.417 & & & \\
\hline Overweight/Under or Normal & 1.4 & {$[0.63 ; 3.08]$} & 0.410 & & & \\
\hline Obese/Under or Normal & 1.7 & {$[0.77 ; 3.92]$} & 0.186 & & & \\
\hline Obesity $(\mathrm{Y} / \mathrm{N})^{*}$ & 2.31 & {$[1.03 ; 5.17]$} & 0.042 & & & \\
\hline Skin Color (non-white/white) & 1.21 & {$[0.65 ; 2.28]$} & 0.546 & & & \\
\hline Per capita family income & 1.00 & {$[0.99 ; 1.00]$} & 0.441 & & & \\
\hline Private Health Insurance $(\mathrm{Y} / \mathrm{N})^{*}$ & 0.73 & {$[0.31 ; 1.70]$} & 0.466 & & & \\
\hline $\begin{array}{l}\text { Marital Status (with/without } \\
\text { partner) }\end{array}$ & 0.75 & {$[0.40 ; 1.39]$} & 0.355 & & & \\
\hline Current Smoking Status $(\mathrm{Y} / \mathrm{N})^{*}$ & 1.22 & {$[0.66 ; 2.26]$} & 0.528 & & & \\
\hline Polypharmacy $(\mathrm{Y} / \mathrm{N})^{*}$ & 4.14 & {$[2.12 ; 8.07]$} & $<0.001$ & & & \\
\hline $\operatorname{COPD}(\mathrm{Y} / \mathrm{N})^{*}$ & 0.59 & {$[0.13 ; 2.79]$} & 0.508 & & & \\
\hline Coronary Heart Disease $(\mathrm{Y} / \mathrm{N})^{*}$ & 2.04 & {$[0.95 ; 4.39]$} & 0.068 & & & \\
\hline Depression $(\mathrm{Y} / \mathrm{N})^{*}$ & 1.18 & {$[0.56 ; 2.49]$} & 0.668 & & & \\
\hline Dyslipidemia $(\mathrm{Y} / \mathrm{N})^{*}$ & 1.10 & {$[0.60 ; 2.03]$} & 0.755 & & & \\
\hline Hypertension $(\mathrm{Y} / \mathrm{N})^{*}$ \& & 3.00 & {$[0.67 ; 13.44]$} & 0.150 & & & \\
\hline Diabetes $(\mathrm{Y} / \mathrm{N})^{*}$ & 2.81 & {$[1.50 ; 5.25]$} & 0.001 & & & \\
\hline Heart Stroke $(\mathrm{Y} / \mathrm{N})^{*}$ & 2.99 & {$[1.09 ; 8.18]$} & 0.033 & & & \\
\hline Number of morbidities & 1.60 & {$[1.17 ; 2.20]$} & 0.001 & & & \\
\hline Poliparmacy $(\mathrm{S} / \mathrm{N})^{*}$ & 4,14 & {$[2.12 ; 8.07]$} & $<0.001$ & 4.05 & {$[2.07 ; 7.93]$} & $<0.001$ \\
\hline
\end{tabular}

Table 3. Summary of the logistic regression analysis results for Polypharmacy (PP). Niterói - RJ, Brazil, 2011/2012

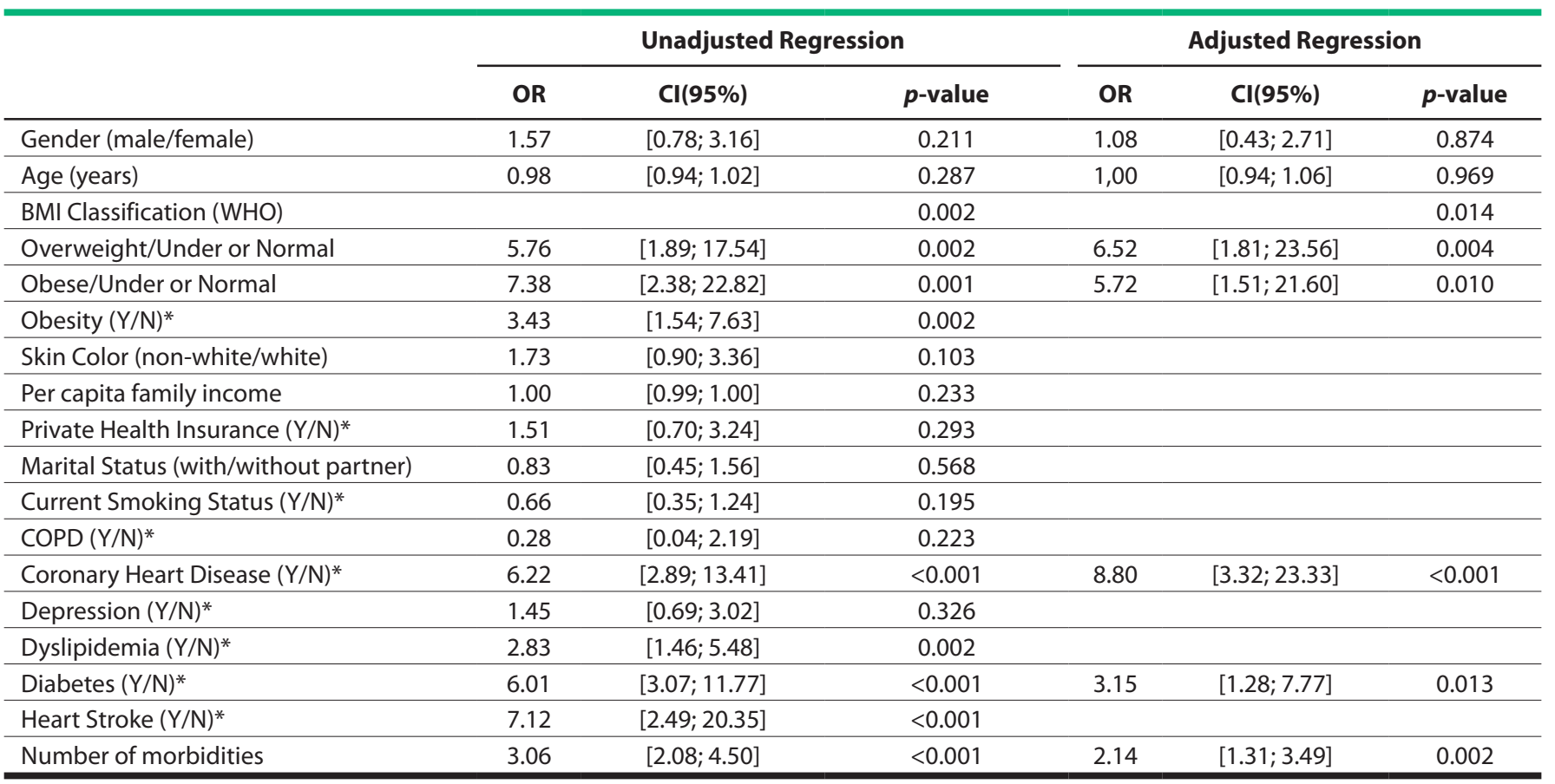

${ }^{*} \mathrm{Y} / \mathrm{N}=\mathrm{Yes} / \mathrm{No}$; OR was not calculated for polypharmacy and hypertension due to the absence of individuals with these conditions. OR - odds ratio; $\mathrm{Cl}$ - control interval; $p$-value - probability value; BMI - body mass index; WHO - World Health Organization; COPD - chronic obstructive pulmonary disease 
$p<0.001$ ), diabetes mellitus ( $\mathrm{OR}=3.2, p=0.013$ ), and number of comorbidities ( $\mathrm{OR}=2.1, p=0.002$ ) (Table 3).

\section{DISCUSSION}

The present study aimed to evaluate the prevalence and factors associated with PP and PIM use in older adults enrolled in the Family Health Program in the municipality of Niterói, Brazil. The Family Health Program aims to assist a pre-designed part of the city and its population. In this way, the physicians that participate in the program follow their patients over time and can establish a relationship of care ${ }^{18}$.

A study conducted in Germany using a primary practice health insurance database showed a PP prevalence rate of $10 \% 5$, different from that found in this study $(23.9 \%)$. However, the German study presented data collected from the national system, and it did not include all the medications the patients were actually using. Studies carried out with patients that used at least one medication, or not, found PP prevalence of rates of $47 \%$ in patients admitted to rheumatology and internal medicine departments at five hospitals in Norway ${ }^{19}$ and of $57 \%$ in geriatric patients (aged $\geq 75$ years) in Sweden 6 . Other studies have reported PP prevalence rates significantly higher, as the Saudi Arabian study that investigated adult medical outpatients at a tertiary care center and observed a rate of $89 \%^{20}$. This important difference between the prevalence rates described in the aforementioned surveys and that found in this study may be explained by the higher level of attention analyzed, since tertiary hospitals are associated with complicated diseases and multiple morbidity. All these studies used the same cutoff point to determine PP.

Studies performed with Intensive Care Unit populations show that older adults in long-term care present higher PP prevalence. On average, the number of medications used by the participants of this study was $3.2 \mathrm{drugs} /$ person/day; meanwhile, other studies have reported numbers between $8^{21}$ and $5.6^{22}$. These lower rates may be explained by the continuous and close care provided by the Family Health Program, which enables a more careful treatment for the patients. However, it is worth mentioning that these rates can be underestimated, because only prescribed medication was considered, and self-medication is a common practice in Brazil. Furthermore, there is a lack of studies conducted in Primary Health Care, which hinders a more accurate comparison, since both aforementioned studies were carried out in tertiary health services.

In the present study, a PIM use prevalence rate of $24.8 \%$ was observed, $45.5 \%$ of the patients were also PP users (data not shown). Mo et al. ${ }^{23}$ identified PIM use in $53.2 \%$ of patients according to the 2012 Beers criteria. In primary care, surveys conducted in Europe ${ }^{24}$ and New Zeland ${ }^{25}$ have observed PIM use prevalence rates of 44 and $42.7 \%$, respectively. Another Brazilian study carried out with older adults in the municipality of Ribeirão Preto, state of Sao Paulo, found a PIM use prevalence rate of $59.2 \%{ }^{13}$. This variability could be a result of the differences in drug availability in different locations, as well as in prescribing habits ${ }^{25}$. In addition; some studies have only included individuals aged $\geq 75$ years, which may explain the higher prevalence of PIM users. Another Brazilian study performed in São Paulo showed a higher PP prevalence rate $(36 \%)$, which suggests that the single Family Health Program of Niterói may have a good impact in health assistance ${ }^{26}$.

High PIM use prevalence was observed for the following drug classes: antihypertensives, antidepressants, vasodilators, digitalis and antiarrhythmics, which concurred with the findings by Farrell et al. ${ }^{12}$, who found that the classes of drugs that ultimately emerged as priorities from the final rankings were associated with mental health, cardiovascular, gastroenterological, and neurological conditions. In this study, $87.8 \%$ of the patients were antihypertensive users, and $10.8 \%(21 / 195)$ of them were also PIM users. From those 21 PIM users, 20 were users of CCBs and PIM, and from the total 44 users of CCBs, $45.5 \%$ were PIM users. For instance, CCBs (specifically Nifedipine) should not be used in elderly patients because of their potential for hypotension and constipation. Some treatments, for a range of mental health and chronic diseases, often highlight drug classes with prolonged use have recently come into question 
(e.g., bisphosphonates, anticonvulsants, etc.). There are several drug classes for which a specialist may have initiated therapy, but a primary care practitioner needs to determine ongoing need (e.g., beta-blockers, antiplatelet agents, cholinesterase inhibitors), or symptomatic treatments in which ongoing benefit versus medication harm remains in doubt (e.g., urinary anticholinergics, opioids, serotonin reuptake inhibitors, typical antipsychotics). This broad range of drug classes suggests that overtreatment occurs throughout the full spectrum of Primary Health Care $^{20}$.

In this study, neither PIM use nor PP were significantly associated with gender or age, unlike what was found in another Brazilian study, in which the female gender was associated with PIM use ${ }^{12}$. After adjusting gender and age, BMI, history of coronary heart disease, diabetes, and number of morbidities were directly associated with PP. All these chronic diseases are associated with multiple complications and often require treatment with multiple drugs, which can explain the higher number of drugs prescribed. In addition, there are behaviors that can contribute to the development and severity of the chronic aspect, such as alcoholism and smoking. Diabetes was especially identified as a risk factor, since it is commonly associated with noncompliance with nutritional guidelines, non-performance of daily glycemic controls, and unhealthy lifestyles ${ }^{27}$. Moreover, a Brazilian study conducted in the state of Goiás that showed association between PP and eutrophic nutritional status, obesity, and use of diet, highlighted the need for nutritional surveillance and monitoring in the elderly population ${ }^{28}$.

After multivariate logistic regression analysis, the main risk factor for PIM use was PP. It was found that PP increases by four times the chances of PIM use. These results show that while effective approaches to discontinuation exist, clinicians still clearly need assistance with negotiating changes with their patients, finding non-pharmacologic approaches to manage symptoms and managing the process of tapering. A Canadian study performed in Toronto ${ }^{29}$ showed that in-home visits were the best way to correctly know the patient medication list, and thus avoid PP. Feedback to the primary physician and physician education on the promotion of rational prescribing ${ }^{30}$ are also some successful strategies to reduce PP. According to Mukete $^{31}$, fixed-dose combinations reduce the medication burden and, consequently, decrease $\mathrm{PP}$, in addition to improving compliance. Furthermore, a study conducted in the Brazilian capital city, Brasília, that showed an increased frequency in the occurrence of clinically significant potential drug-drug interactions in dementia patients, reinforced the need for drug-drug interaction studies in specific elderly populations ${ }^{32}$.

Once there are no antidiabetic drugs in the Beers list, it is unexpected to find a relationship between diabetes mellitus and PIM use. However, diabetes mellitus is part of the metabolic syndrome that, according to WHO includes obesity, hypertension, diabetes mellitus, and dyslipidemia. All of these conditions are connected to each other and superpose their effects. Thus, patients do not usually have only diabetes, but also metabolic syndrome, and it is understandable how usually is related to PP. In addition, some of these conditions present the use of inappropriate drugs in their treatment, which explains the relationship between diabetes mellitus and PIM use.

This study presents several limitations. First, it is important to highlight that all its participants were Brazilian patients and professionals; therefore, the results obtained reflect social and economic conditions and singularities of the Brazilian health system. It is worth noting that, although the Brazilian health system is universal and egalitarian, the drugs offered by this system are still limited. Another limitation to this study regards its sample, which was mainly composed of older female adults (68.5\%), increasing BMI levels and influencing the profile of most prevalent diseases found. It is also important to highlight that a qualitative definition to inappropriate medication was not used but, in practice, physicians have to consider the multiple variables involved in each case to decide if a certain drug should be used on a patient. An exclusive quantitative definition of PP was also used, which is another limitation to this study. A more complex definition refers to qualitative PP, which can be considered as the prescription, administration, and use of more drugs than needed for the patient, respecting the rationalization of pharmacology therapy. As in all cross-sectional studies, this survey did not consider temporality as a causal effect. It considered only prescribed medications at the time of interview, and it did not include self-medication and lost or forgotten prescriptions. This fact 
may underestimate the prevalence of PP and PIM use. Although the medications taken by the study participants were accurately recorded, medical comorbidities were not evaluated; which means that drugs to be avoided in certain diseases were not included in the prevalence of PIM use. It is important to emphasize that there is no Brazilian list for inappropriate medication for elderly people. Despite the fact that the Beers list is very commonly used worldwide, it is not complete for Brazilian outpatient clinic, which limited the evaluation intended in this study.

Prevalence rates of 23.9 and $24.8 \%$ were found for PP and PIM use, respectively. These rates are lower than those reported in another studies; however, the associations of PP with PIM use and of PP with BMI, history of coronary heart disease, diabetes, and number of morbidities show that these chronic and high prevalent diseases are associated with PIM use and PP. These results show the need to adequately monitor the prescriptions and train health professionals to identify risk groups and inappropriate medications in order to improve both adherence and affectivity of treatments and prescriptions security.

\section{REFERENCES}

1. Brook RH, Kamberg CJ, Mayer-Oakes A, Beers MH, Raube K, Steiner A. Appropriateness of acute medical care for the elderly: an analysis of the literature. Health Policy. 1990;14(3):225-42. http://dx.doi. org/10.1016/0168-8510(90)90037-E. PMid:10113351.

2. United Nations. Department of Economic and Social Affairs. World Population Ageing 2015 [Internet] New York: United Nations; 2015 [cited 2018 Apr 12]. Available from: http://www.un.org/en/development/ desa/population/publications/pdf/ageing/WPA2015_Report.pdf

3. Heath I. Overdiagnosis: when good intentions meet vested interests: an essay by lona Heath. BMJ. 2013;347:f6361. http://dx.doi.org/10.1136/bmj.f6361. PMid:24162944.

4. Huang AR, Mallet L, Rochefort CM, Eguale T, Buckeridge DL, Tamblyn R. Medication-related falls in the elderly: causative factors and preventive strategies. Drugs Aging. 2012;29(5):359-76. http://dx.doi. org/10.2165/11599460-000000000-00000. PMid:22550966.

5. Grimmsmann T, Himmel W. Polypharmacy in primary care practices: An analysis using a large health insurance database. Pharmacoepidemiol Drug Saf. 2009;18(12):1206-13. http://dx.doi.org/10.1002/ pds.1841. PMid:19795368.

6. Haider SI, Johnell K, Weitoft GR, Thorslund M, Fastbom J. The influence of educational level on polypharmacy and inappropriate drug use: A register-based study of more than 600,000 older people. J Am Geriatr Soc. 2009;57(1):62-9. http://dx.doi.org/10.1111/j.1532-5415.2008.02040.x. PMid:19054196.

7. Gnjidic D, Hilmer SN, Blyth FM, Naganathan V, Waite L, Seibel MJ, et al. Polypharmacy cutoff and outcomes: five or more medicines were used to identify community-dwelling older men at risk of different adverse outcomes. J Clin Epidemiol. 2012;65(9):989-95. http://dx.doi.org/10.1016/j.jclinepi.2012.02.018. PMid:22742913.

8. Rosted E, Schultz M, Sanders S. Frailty and polypharmacy in elderly patients are associated with a high readmission risk. Dan Med J. 2016;63(9) PMid:27585531.

9. Sonal Sekhar M, Adheena Mary C, Anju PG, Hamsa NA. Study on drug related hospital admissions in a tertiary care hospital in South India. Saudi Pharm J. 2011;19(4):273-8. http://dx.doi.org/10.1016/j. jsps.2011.04.004. PMid:23960769.

10. Maher RL, Hanlon J, Hajjar ER. Clinical consequences of polypharmacy in elderly. Expert Opin Drug Saf. 2014;13(1):57-65. http://dx.doi.org/10.1517/14740338.2013.827660. PMid:24073682.

11. Zia A, Kamaruzzaman SB, Tan MP. Polypharmacy and falls in older people: Balancing evidence-based medicine against falls risk. Postgrad Med. 2015;127(3):330-7. http://dx.doi.org/10.1080/00325481.2014. 996112. PMid:25539567.

12. Farrell B, Tsang C, Raman-Wilms L, Irving H, Conklin J, Pottie K. What are priorities for deprescribing for elderly patients? Capturing the voice of practitiones? Modified Delphi process. PLoS One. 2015;10(4):e0122246. http://dx.doi.org/10.1371/journal.pone.0122246.

13. Luiza GRM, Evandro TM, Jose LJA, Dayse MSC, Josemir RL, Kang HC, et al. Prevalence of chronic diseases in individuals assisted by the family health program in Niteroi, Brazil: evaluation of selection bias and protocol. Int J Med Res Health Sci. 2015;4(3):587-96. http://dx.doi.org/10.5958/2319-5886.2015.00113.7.

14. American Geriatrics Society 2012 Beers Criteria Update Expert Panel. American Geriatrics Society updated Beers Criteria for potentially inappropriate medication use in older adults. J Am Geriatr Soc. 2012;60(4):61631. http://dx.doi.org/10.1111/j.1532-5415.2012.03923.x. PMid:22376048. 
15. Wucherer D, Eichler T, Hertel J, Kilimann I, Richter S, Michalowsky B, et al. Potentially inappropriate medication in community-dwelling primary care patients who were screened positive for dementia. J Alzheimers Dis. 2017;55(2):691-701.

16. Baldoni AO, Ayres LR, Martinez EZ, Dewulf NLS, Santos V, Pereira LRL. Factors associated with potentially inappropriate medications use by the elderly according to Beers criteria 2003 and 2012. Int J Clin Pharm. 2014;36(2):316-24. http://dx.doi.org/10.1007/s11096-013-9880-y. PMid:24271923.

17. Araújo C, Chaimowicz F, Margalhães S. Uso de medicamentos inadequados e polifarmácia entre idosos do Programa Saúde da Família. Lat Am J Pharm. 2010;29(2):178-84.

18. Hübner LCM, Franco TB. Niteroi's family doctor program as a strategy to implement a care model that addresses SUS's principles and guidelines. Physis. 2007

19. Viktil KK, Blix HS, Moger TA, Reikvam A. Polypharmacy as commonly defined is an indicator of limited value in the assessment of drug-related problems. Br J Clin Pharmacol. 2007;63(2):187-95. http://dx.doi. org/10.1111/j.1365-2125.2006.02744.x. PMid:16939529.

20. Salih SB, Durihim H, Almodaimegh H, Yousuf M, Tamim H. Prevalence and associated factors of polypharmacy among adult Saudi medical outpatients at a tertiary care center. J Family Community Med. 2013;20(3):162-7. http://dx.doi.org/10.4103/2230-8229.121987. PMid:24672273.

21. Jensen LD, Andersen $\mathrm{O}$, Hallin M, Petersen J. Potentially inappropriate medication related to weakness in older acute medical patients. Int J Clin Pharm. 2014;36(3):570-80. http://dx.doi.org/10.1007/s11096014-9940-y. PMid:24723261.

22. Millán-Calenti JC, Martínez-Isasi S, Lorenzo-López L, Maseda A. Morbidity and medication consumption among users of home telecare services. Health Soc Care Community. 2017;25(3):888-900. http://dx.doi. org/10.1111/hsc.12377. PMid:27487761.

23. Mo L, Yang X, He J, Dong B. Evaluation of Potentially Inappropriate Medications in Older Inpatients in China. J Am Geriatr Soc. 2014;62(11):2216-8. http://dx.doi.org/10.1111/jgs.13118. PMid:25413197.

24. Blanco-Reina E, Ariza-Zafra G, Ocanã-Riola R, León-Ortiz M. 2012 American Geriatrics Society Beers Criteria: Enhanced Applicability for Detecting Potentially Inappropriate Medications in European Older Adults? A Comparison with the Screening Tool of Older Person's Potentially Inappropriate Prescriptions. J Am Geriatr Soc. 2014;62(7):1217-23. http://dx.doi.org/10.1111/jgs.12891. PMid:24917083.

25. Nishtala PS, Bagge ML, Campbell AJ, Tordoff JM. Potentially inappropriate medicines in a cohort of community-dwelling older people in New Zealand. Geriatr Gerontol Int. 2014;14(1):89-93. http://dx.doi. org/10.1111/ggi.12059. PMid:23530567.

26. Carvalho MFC, Romano-Lieber NS, Bergsten-Mendes G, Secoli SR, Ribeiro E, Lebrão ML, et al. Polypharmacy among the elderly in the city of São Paulo, Brazil - SABE Study. Rev Bras Epidemiol. 2012 Dec;15(4):817-27. http://dx.doi.org/10.1590/S1415-790X2012000400013. PMid:23515777.

27. Weber P, Weberova D, Meluzinova H. How to approach to the therapy of diabetes in the elderly. Adv Gerontol. 2014;27(3):519-30. PMid:25827001.

28. Silveira EA, Dalastra L, Pagotto V. Polypharmacy, chronic diseases and nutritional markers in communitydwelling older. Rev Bras Epidemiol. 2014;17(4):818-29. http://dx.doi.org/10.1590/1809-4503201400040002. PMid:25388483.

29. Kroenke K, Pinholt EM. Reducing polypharmacy in the elderly. A controlled trial of physician feedback. J Am Geriatr Soc. 1990;38(1):31-6. http://dx.doi.org/10.1111/j.1532-5415.1990.tb01593.x. PMid:2404053.

30. Hogerzeil HV. Promoting rational prescribing: an international perspective. Br J Clin Pharmacol. 1995;39(1):1-6. http://dx.doi.org/10.1111/j.1365-2125.1995.tb04402.x. PMid:7756093.

31. Mukete BN, Ferdinand KC. Polypharmacy in older adults with hypertension: a comprehensive review. J Clin Hypertens (Greenwich). 2016;18(1):10-8. http://dx.doi.org/10.1111/jch.12624. PMid:26215211.

32. Felipe F, Diniz JSV, Medeiros-Souza P, Freitas MPD, Camargos EF, Kusano LTE, et al. Potential high-risk drug-drug interactions among elderly outpatients with dementia: a cross-sectional study. Geriatrics, Gerontology and Aging. 2015;9(2):21-5. 